\title{
Pengaruh Kualitas Pelayanan Multy Payment Online (MP0) Terhadap Kepuasan Nasabah Pegadaian Syariah Cabang Jokotole Pamekasan
}

\author{
Anna Fijriatul Latifah1), Mohammad Bashri Asy'ari'2) \\ 1), 2)Institut Agama Islam Negeri Madura, Pamekasan, Indonesia \\ Corresponding author : bashri@yahoo.com
}

\begin{abstract}
:
Service quality is one of the keywords to reach the customer satisfactions. The development and competition of sharia-based financial institutions are beginning to emerge which can certainly have an impact on the comfort and satisfaction of members. This reality generates a big question, namely is there an effect of the quality of Multy Payment Online service on customer satisfaction at the jokotole pamekasan branch of the Syariah pawnshop. The results of the simple linear regression coefficient research indicate that the quality of Multy Payment Online Services has a positive and significant effect on customer satisfaction at the jokotole Pamekasan Syariah Pegadaian Branch. Based on the results of the t test, it shows that the $t$ value for service quality is obtained at $1.530>t$ table 1.972 with a significant level of 0.044 which is smaller than 0.05 , this indicates that $t$ count $>t$ table and a significant level of 0.044 $<0.05$ then Ha accepted, meaning that the Quality of Online Multy Payment Service has an influence on customer satisfaction. The coefficient of determination is known as $\mathrm{R}$ square 0.021 or $2.1 \%$, which means that the independent variable (Quality of Multy Payment Online Services) is able to explain the dependent variable (customer satisfaction) of $2.4 \%$ while the rest $(100 \%-2.4 \%=97,9 \%)$ is influenced by other variables which are not taken into account in this analysis.
\end{abstract}

Keywords: Service Quality, Customer Satisfaction

\begin{abstract}
Abstrak:
Kualitas pelayanan adalah salah satu kata kunci untuk mencapai kepuasan nasabahnya. Pegadaian Syariah Cabang Jokotole di saing untuk memenuhi kepuasan nasabahnya dengan memiliki aplikasi Multy Payment Online. Perkembangan dan persaingan lembaga keuangan yang berbasis syariah mulai bermunculan dapat dipastikan berdampak pada kenyamanan dan kepuasan anggota sehingga Pegadaian Syariah cabang jokotole Pamekasan dituntut untuk bisa memuaskan anggotanya dan menjadi loyal. Dari realita tersebut menghasilkan pertanyaan besar yaitu adakah pengaruh kualitas pelayanan Multy Payment Online terhadap kepuasan nasabah pegadaian syariah cabang jokotole pamekasan. Hasil penelitian koefisien regresi linier sederhana menunjukkan bahwa kualitas Pelayanan Multy Payment Online berpengaruh posistif dan signifikan terhadap kepuasan nasabah pada Pegadaian Syariah Cabang jokotole Pamekasan. Berdasarkan hasil uji t menunjukkan bahwa nilai thitung untuk kualitas pelayanan diperoleh sebesar 1,530 $>\mathrm{t}$ tabel 1,972 dengan taraf signifikan sebesar 0,044 yang lebih kecil dari 0,05, hal ini menunjukkan bahwa t hitung $>t$ tabel dan taraf signifikan sebesar 0,044 < 0,05 maka Ha diterima, artinya Kualitas Pelayanan Multy Payment Online mempunyai pengaruh terhadap kepuasan nasabah. Serta koefisien determinasi diketahui $\mathrm{R}$ square 0,021 atau 2,1\% yang berarti bahwa variabel independen (Kualitas Pelayanan Multy Payment Online) mampu menjelaskan Variabel dependen (kepuasan Nasabah) sebesar 2,4\% sedangkan sisanya $(100 \%-2,4 \%=97,9 \%)$ dipengaruhi oleh variabel-variabel lainnya yang tidak diperhitungkan dalam analisis ini.
\end{abstract}

Kata Kunci: Kualitas Pelayanan, Kepuasan nasabah 


\section{PENDAHULUAN}

Di era globalisasi yang mana perkembangan teknologi informasi saat ini, teknologi informasi berkembang pesat. Sebagai negara berkembang Indonesia, harus selalu mengikuti perkembangan dan memanfaatan teknologi informasi yang ada untuk mengejar ketertinggalan dalam bidang teknologi dari negara-negara maju. Kemajuan pesat teknologi komputer baik perangkat keras, perangkat lunak, sistem host to host, sistem jaringan komunikasi data memberikan dampak luar biasa kepada jasa perbankan secara elektronik. ${ }^{1}$ Internet sebagai salah satu media teknologi informasi yang modern, telah meyebar dan berkembang pesat dalam segala aspek kehidupan masyarakat Indonesia dan seluruh dunia tak terkecuali dalam bidang perekonomian. ${ }^{2}$ Perkembangan teknologi yang berkembang memungkinkan perbankan memanfaatkan teknologi dalam proses pelayanannya dengan meluncurkan layanan transaksi perbankan berbasis teknologi, yaitu sistem pembayaran online disebut juga payment online.

Seiring dengan perkembangan kesadaraan kaum muslim untuk bertansaksi secara syariah, perbankan syariah berkembang maju. Saat ini sudah banyak bermunculan bank berbasis syariah yang sistemnya menggunakan prinsip bagi hasil. Dengan banyaknya lembaga keuangan syariah membuktikan bahwa eksistensi dan pentingnya lembaga keuangan syariah, lembaga keungan non bank juga tidak kalah bersaing dengan bank. Pegadaian merupakan salah satu lembaga keuangan non bank milik negara yang melakukan kredit kepada masyarakat dengan sistem gadai, ${ }^{3}$ belakangan bersamaan dengan perkembangan produk-produk berbasis syariah yang kian marak di Indonesia, mengalami perubahan dengan diberlakunya prinsip-prinsip syariah. ${ }^{4}$

Kualitas pelayanan merupakan salah satu jaminan terbaik untuk menciptakan dan mempertahankan kesetiaan konsumen atau sebagai benteng pertahanan dalam penghadapi persaingan global. Semakin baik kualitas pelayanan yang diberikan suatu perusahaan, maka semakin baik pula persepsi/ penilaian konsumen terhadap kualitas pelayanan yang ditawarkan perusahaan. Kualitas pelayanan merupakan salah satu faktor penting yang digunakan pelanggan untuk mengevaluasi kinerja jasa suatu perusahaan dibanding dengan penawaran perusahaan lain. Kualitas pelanggan yang tinggi adalah kinerja pelayanan yang diharapkan melebihi atau sama dengan kinerja yang dipersepsikan oleh pelanggan. ${ }^{5}$

Menurut Kotler menyebutkan bahwa kepuasan konsumen merupakan funsi dari pandangan terhadap kinerja produk atau jasa dan harapan konsumen. ${ }^{6}$ Kepuasan pelanggan dipandang sebagai konsep multy dimensi yang melibatkan biaya, kemudahan sarana, aspek teknis dan interpersonal serta hasil akhir kepuasan ini terjadi sebagai hasil berpengaruhnya

\footnotetext{
${ }^{1}$ Maryanto Supriono, Buku Pintar Perbankan, (Yogyakarta: CV Andi Offset, 2011), hlm.65.

2 Hestin Mulyasari Dkk, "Analisis Jenis Pembayaran Elektronik Dalam Transaksi E-Commerce Di Indonesia", ISSN : 2089-9813 Yogyakarta15 Maret 2014, Jurnal : Seminar Nasional Teknologi Informasi Dan Komunikasi 2014 (SENTIKA) Diakses Tanggal 4 April 2018 Pukul 12.43 WIB.

${ }^{3}$ Nining Catur Pawestriningtyas Dkk, "Pengaruh Kualitas Layanan Jasa Terhadap Nasabah (Survei Pada Nasabah Pegadaian Kantor Cabang Syariah Tlobo Mas Malang)”, Vol. 32 No. 2 Maret 2016, Jurnal Administrasi Bisnis, Diakses Tanggal 29 April 2018 Pukul 05.25 WIB.

${ }^{4}$ Andri Soemitra, “ Bank Dan Lembaga Keuangan Syariah”,(Jakarta: Kencana Perdana Media,2009), Hlm.276.

5 Willy Tri Hardiyanto Dkk, "Analisis Pengaruh Kualitas Pelayanan Terhadap Kepuasan Pelanggan Dalam Pembayaran Rekening Listrik (Studi Pada Unit Pelayanan Pelanggan Di Probolinggo)", Vol,2 No,2 Juli-Desember 2012, Diakses Tanggal 29 September 2018 Pukul 08.00 WIB.

6 Tony Wijaya, “ Manajemen Kualitas Jasa”,(Jakarta: PT. Indenks, 2011), hlm. 2
} 
keterampilan, pengetahuan, perilaku, sikap dan penyedia sarana. ${ }^{7}$ Kepuasan pelanggan dipengaruhi oleh persepsi kualitas jasa, kualitas produk, harga dan faktor yang bersifat pribadi serta yang situasi sesaat. Salah satu faktor yang berfokus pada lima dimensi kualitas jasa menurut Zeithmal dan Berry yaitu reliabilitas, daya tanggap, jaminan, empati dan bukti fisik. 8

Pegadaian hadir di Indonesia dalam bentuk kerja sama bank syariah dengan perum pegadaian membuntuk unit layanan gadai syariah dibeberapa kota di Indonesia. Adapun konsep operasi pegadaian syariah mengacu pada sistem adminitasi modern, yaitu rasional, efisiensidan efektifitas yang diseralaskan dengan nilai islam. Fungsi operasi pegadaian syariah dijalankan oleh kantor-kantor cabang pegadaian syraiah/unit layanan gadai syariah (ULGS) sebagai salah satu organisasi diabwah binaan difisi usaha lain perum pegadaian. ${ }^{9}$ Pegadain syariah merupakan bagian dari pegadaian umum yang secara kelembagaan merupakan perusahaan milik negara yang didirikan dengan peraturan pemerintah dan ia sebagai badan hukum peraturan pemerintah yang menerangkan tentang pegadaian yaitu peraturan nomor 103 tahun 2000 tentang perusahaan umum (perum pegadaian). Pegadaian syariah didirikan dan diatur berdasarkan ketentuan-ketentuan yang ada didalam undangundang nomor 19/Prp tahun 1960 hal ini menurut pasal 2 ayat 2 undang-undang nomor 9 tahun 1969 yang seluruh modalnya dimiliki oleh negara berupa kekayaan negara yang dipisahkan dan tidak terbagi atas saham. Dengan demikian, pegadaian syariah merupakan badan hukum yang dimiliki oleh negara dan modal seluruhnya milik negara dan tidak terbagi atas saham. ${ }^{10}$ Dengan berjalannya waktu dan semakin berkembangnya pegadaian maka tanggal 2 februari 2006 didiranlah pegadaian syariah cabang Jokotole Pamekasan.

Pada sektor lembaga keuangan non bank, pegadaian syariah merupakan salah satu yang juga memanfaatkan teknologi sebagai sarana untuk dapat meningkatkan pelayanan demi kepuasan nasabahnya dengan meluncurkan produk berupa aplikasi sistem pembayaran online yang diberi nama Multy Payment Online (MPO). Terhitung mulai tanggal 1 juni 2013, kantor cabang dan unit PT pegadaian (persero) sudah dapat melayani pembayaran listrik, pembayaran PDAM, pemeblian tiket ketera api dan pembelian pulsa elektrik semua operator seluler.

Payment point bank (PPOB) system, yaitu sistem pembayaran rekening secara tunai melalui teknologi tinggi dengan menggunakan perangkat lunak yang di desain secara khusus dengan memberikan kemudahan kepada masyarakat. perubahan ini dilakukan dengan mengoptimalkan pemanfaatan kemajuan teknologi wileress seperti GPRS serta kemampuan bank-bank memberdayakan para mitranya. ${ }^{11}$ Aplikasi payment online pada sistem perbankan merupakan suatu hal yang sudah biasa, karena perbankan akan melakukan inovasi baru dengan mengembangkan teknologi informasi yang ada untuk dapat meningkatkan pelayanan demi kepuasan dan kenyamanan nasabahnya. Transaksi elektronik menguntungkan karena

\footnotetext{
${ }^{7}$ Sonya Maharani " Analisis Pengaruh Kualitas Pelayanan Terhadap Pelanggan Dalam Pembayaran Rekening Listrik (Studi Pada Unit Pelayanan Pelanggan Semarang Barat)", Universitas Diponegore Semarang, 2010.

8 Fandiy Tjiptono Dan Gregorius Candra, "Service Quality \& Satisfaction" (Yogyakarta: CV. Andi Offset, 2005), Hlm. 198.

${ }^{9}$ Ibid, Hlm. 278.

${ }^{10}$ Ahmad Rodoni, “Asuransi Dan Pegadaian Yariah”, (Jakarta: Mitra Wacana Media, 2015), Hlm. 61.

11 Maulana Yusuf Dan Medina Kurniawan, "Pengaruh Sistem Pembayaran Listrik Online Payment Point Online Bank Terhdap Pengendalian Internal Kas Pada PT PLN (Persero) DJBB", Vol 6 No 1 April 2012 Jurnal Ekonomi, Bisnis Dan Enterpreneurship Diakses Tanggal 7 Mei 2018 Pukul 14.10 WIB.
} 
dapat mengurani biaya transkasi bisnis dan dapat memperbaiki kualitas pelayanan kepada pelanggan. ${ }^{12}$

Multy payment online (MPO) merupakan solusi pembayaran cepat yang memberikan kemudahan kepada nasabahnya tanpa harus memiliki rekening bank. Pembayaran secara real time, sehingga memberik kepastian dan kenyamanan dalam bertansaksi. Nasabah cukup datang ke oultet pegadaian dengan membawa dan penyerahkan nomer pelanggan untuk tagihan listrik, telepon, pulsa ponsel, PDAM, tiket kereta api dan lain sebagainya. Pengguna layanan MPO ini setiap hari berkisar antara 20-30 nasabah setiap harinya. ${ }^{13}$

Pelayanan multy payment online (MPO) ini diharapkan dapat membantu dan perpermudah nasabah dalam melakukan proses transaksi pembayaran. Sehingga timbul kepuasan bagi anggota pengguna layanan MPO dengan transkasi yang mudah, cepat, akurat, aman, dan efisien yang nantinya akan menguntungkan pihak pegadaian dan nasabah yang merasa untung dan puas dengan pelayanan yang diberikan oleh pegadaian syariah cabang jokotole pamekasan melalui pelayanan MPO, jika pelayanan sesuai dengan mereka (nasabah) yang diharapkan.

Berdasarkan latar belakang masalah yang dipaparkan maka peneliti tertarik ingin melakukan penelitian yang berjudul "Pengaruh Kualitas Pelayanan Multy Payment Online (MPO) Terhadap Kepuasan Nasabah Pagadaian Syariah Cabang Jokotole Pamekasan”.

\section{METODE PENELITIAN}

\section{A. Rancangan Penelitian}

Penelitian ini menggunakan pendekatan kuantitaif yakni, penelitian dengan menggunakan analisis data statistik atau angka-angka. Sedangkan jenis menelitian ini menggunakan analisis regresi linear sederhana, yakni untuk mentahui besarnya pengaruh kualitas pelayanan multy payment online terhadap kepuasan nasabah pegadaian syariah cabang jokotole pamekasan. Oleh karena itu penelitian ini termasuk kategori kuantitatif regresi maka ada dua variabel yang melibatkan yakni variabel X (kualitas pelayanan multy payment online) dan variabel Y (kepuasan nasabah)

\section{B. Populasi Dan Sampel}

\section{Populasi}

Populasi merupakan keseluran objek atau subjek yang berada pada suatu wilayah dan memenuhi syarat-syarat tertentu berkaitan dengan masalah penelitian, atau keseluruhan unit atau individu dalam ruang lingkup tang akan diteliti. ${ }^{14}$

Jadi, jumlah populasi dalam penelitian ini yaitu sebesar 600 nasabah multy payment online.

\section{Teknik Pemgambilan Sampel}

Adapun jumlah nasabah pengguna multy payment online di pegadaian syariah cabang jokotole pamekasan yaitu, 600 nasabah. Maka peneliti dalam pengambilan sampelnya menggunakan rumus Slovin sebagai berikut:

$$
n=\frac{N}{1+N e^{2}}
$$

\section{Keterangan :}

\footnotetext{
12 Erikson Damanik,"Perancangan Sistem Informasi Pembayaran Online Menggunakan Paymen Gateway", Vol 13 No 1 April 2012 Jurnal JSM STIMK Mikro Skill Di Akses Tanggal 7 Mei 2018 Pukul 14.10 WIB.

${ }^{13}$ Andri, Wawancara Salah Saru Karyawan Pegadaian Syariah Cabang Jokotole Pamekasan

${ }^{14}$ Nanang Martono," Metode Penelitian Kuantitatif; Analisis Isi Dan Analisis Data Sekunder", (Jakarta: Rajawali Pers,2012), Hlm. 74.
} 
$\mathrm{N}=$ ukuran populasi

$\mathrm{n}=$ ukuran sampel

$\mathrm{e}=$ persen kelonggaran ketidak telitian karena kesalahan pengambilan sampel

yang masih dapat ditolelir dan diinginkan.

Besarnya populasi diketahui sebesar 600 nasabah pengguna multy payment online. Peneliti menggunakan perkiraan tingkat kesalahan 5\% mengingat pada rumus slovin perkiraan kesalahan (nilai galat pendugaan) didasarkan atau pertimbangan peneliti.

$$
\begin{aligned}
& n=\frac{N}{1+N e^{2}} \\
& n=\frac{600}{1+\left(6 0 0 x \left(5 \% \%^{2)}\right.\right.} \\
& n=\frac{600}{1+\left(600 x(0,05)^{2}\right)} \\
& n=\frac{600}{1+(600 x 0,0025)} \\
& n=\frac{600}{1+1,5} \\
& n=\frac{600}{2,5} \\
& n=240
\end{aligned}
$$

Jadi, jumlah responden yanga kan diambil adalah sebanyak 240 responden

Desain pengambilan sampel yang digunakan dalam penelitian ini menggunakan teknik penarikan sampel non probality dengan teknik purposive sampling, yaitu metode pengambilan sampel yang dipilih dengan cermat sehingga relevan dengan struktur penelitian, dimana pengembalian sampel dengan mengambil sample orang-orang yang dipilih oleh penulis menurut ciri-ciri spesifik dan karakteristik tertentu.

\section{Sumber data}

Setiap penelitian memerlukan data karena data merupakan sumber informasi yang dapat memberikan data utama kepada peneliti tentang ada ataupun tidaknya masalah yang akan diteliti.

Jadi dapat disimpulkan bahwa sumber data dalam pnelitian ini yaitu: 15

a. Sumber data primer

b. Sumber data sekunder

\section{Instrumen Penelitian}

Instrumen penelitian adalah alat atau fasilitas yang digunakan oleh peneliti dalam mengumpulkan data pekerjaannya lebih mudah dan hasilnya lebih baik. Instrumen yang digunakan dalam penelitian ini berupa angket (koesioner) dokumentasi dan wawancara tujuannya adalah untuk memperkaya informasi tentang penelitian yang dilakukan oleh peneliti.

\section{Kuesioner (angket)}

Tujuan utama penggunaan kuesioner dalam peneltian yaitu:

a. Memperoleh informasi yang lebih relefan dengan tujuan penelitian

b. Mengumpulkan informasi dengan reabilitas dan validitas yang tinggi. 16

\footnotetext{
${ }^{15}$ Misbahun Dan Iqbal Hasan, “Analisis Data Penelitian Dengan Statistik”, (Jakarta: PT Bumi Aksara,2013), Hlm. 21
} 
Menurut cara memberikan repons, angket dibedakan menjadi dua jenis yaitu: angket terbuka dan angket tertutup.

a. Angket terbuka

b. Angket tertutup

Jenis angket yang digunakan oleh penliti yaitu menggunakan angket tertutup dalam pengumpulkan datanya.

\section{Dokumentasi}

Peneliti menguraikan langkah serta teknik dalam mengambilan data selama melakukan penelitian di pegadaian syariah cabang jokotole pamekasan berupa data sekunder yang diperoleh dari berbagai sumber, baik dari literatur, artikel, data perusahaan dan lain-lain yang dianggap relevan dengan penelitian. Data yang digunakan dalam dokumentasi yaitu profil pegadaian syariah, status hukum pegadaian syariah, struktur organisasi pegadaian syariah, produk-produk pegadaian syariah dan foto penyebaran kuesiouner di Pegadaian Syariah Cabang Jokotole Pamekasan.

\section{Pengumpulan Data}

Adapun langkah-langkah sebagai berikut:

a. Pengumpulan Data Melalui Angket

Adapun langkah-langkah pengumpulan data sebagai berikut:

1. Peneliti datang ke lokasi penelitian yaitu pegadaian syariah cabang jokotole pamekaan selama 30 hari.

2. Peneliti memberikan angket kepada responden nasabah pengguna layanan multy payment online.

3. Peneliti mengambil kembali angket dari responden untuk dilakukan penelitian.

4. Memberikan pembobotan untuk setiap pertanyaan tertutup yang berskala ordinal. Selanjutnya akan diberik skor 5-4-3-2-1, dengan menggunkan skala likert (sangat setuju; setuju; ragu-ragu; tidak setuju; sangat tidak setuju).

\section{b. Pengumpulan Data Melalui Doumentasi}

1. Mencari informasi untuk dicatat sesuai dengan variabel penelitian yang telah ditentukan

2. Mengadakan penctatan langsung terhadap dokumen atau arsip yang berhubungan dengan masalah yang diteliti.

\section{E. Analisis data}

Analisis data merupakan metode penggambaran secara objektif, sistematis dengan menggunkana teknik deskriptif kuantitatif dari setiap perilaku simbolis. ${ }^{17}$ Adapun langkah dalam menganalisis data adalah sebagai berikut:

\section{Mencari data mentah}

Data mentah yang diperoleh merupakan data priimer yaitu langsung dari sumber yang diteliti berupa wawancara degan nasabah yang menggunakan layanan multy payment online dengan menggunkan angket.

\section{Menghitung statistik deskriptif}

Untuk memberikan gambaran demografi responden penelitian dan diskripsi frekuensi menegnai variabel penelitian pengaruh kualitas pelayanan multy payment online terhadap kepuasan nasabah pegadaian syariah cabang jokotole pamekasan.

\section{Melalalui Uji Kualitas Data}

\footnotetext{
${ }^{16}$ Misbahun dan Iqbal Hasan, “Analisis Data Penelitian Statistik”,(Jakarta: PT Bumi Anksara,2013), hlm. 199

${ }^{17}$ Martono, “Metode Penelitian Kuantitatif”, hlm.86.
} 


\section{a. Validitas}

Pengujian validitas ini menggunakan alat bantu SPSS koefisien korelasi tiap item akan dibandingkan dengan $r$ tabel dengan taraf signifikasi 5\%. Uji validitas sebaiknya dilakukan pada setiap butir pertanyaan di uji validitasnya. Hasil $r$ dihitung dibandingkan dengan $r$ tabel, dimana $\mathrm{df}=\mathrm{n}-2$ dengan sig 5\%. Jika $r$ tabel $<\mathrm{r}$ hitung valid. ${ }^{18}$

\section{b. Reabilitas}

Bila hasil koefisien reabilitas dari semua variabel menunjukkan positif dan signifikan, maka instrumen tersebut dinyatakan reliabel. Uji reabilitas dapat dilakukan secara bersama-sama terhadap seluruh butir pertanyaan. Jika nilai alpha > 0,60 maka reliabel. ${ }^{19}$

\section{Uji Asumsi Klasik}

Pengujian ini untuk menilai baik tidaknya model regresi yang dikembangkan pada penelitian ini.

\section{a. Uji Normalis}

Alat yang dapat digunakan untuk menguji normalitas data dan populasi sangat banyak modelnya. Model yang mana yang mau dipakai sangat tergantung pada kebiasaan para peneliti, tidak mutlak harus model A atau model B. Para pemakai ada kebebasan untuk menentukan model analisi yang digunakan.20 Untuk menguji normalis data dengan mengunakan SPSS terdapat tiga pilihan (alternatif). Ketiga alternatif uji normalis mengunakan SPSS tersebut berupa:

1) Menggunakan analisis statistik deskriptif untuk frekuensi.

2) Menggunakan analisis statistik deskriptif untuk eksplor.

3) Nonparametrik tes untuk 1-sampel K-S. ${ }^{21}$

\section{b. Uji Autokrelasi}

Korelasi antara anggota seri observasi yang disusun menurt urutan waktu (seperti data time series) atau urutan temoat / ruang (data cross section), atau orelasi yang timbul pada dirinya sendiri. Pengujian autokorelasi ini dimaksudkan untuk mengetahui apakah terjadi korelasi diantara data pengamatan atau tidak. Adanya autokorelasi dapat mengakibatkan penaksir mempunyai varians tidak minimum dan uji-t dapat digunakan, karena akan memberikan kesimpulan yang salah. ${ }^{22}$

\section{c. Uji Heteroskedastisitas}

Uji asumsi heteroskedastisitas ini dimaksudkan untuk mengetahui apakah variasi residual absolut sama atau tidak sama untuk semua pengamatan. Apabila asumsi tidak terjadi heteroskedastisitas ini tidak terpenuhi, maka penaksir menjadi tidak lagi efisien baik dalam sampel kecil maupun besar dan estimasi koefisien dapat dikatan menjadi kurang akurat.

\section{Uji Hipotesis}

\section{a. Analisis Regresi Linier Sederhana}

Penelitian ini menggunakan analisis regresi linier sederhana. Yang dimaksud dengan regresi linier sederhana adalah merupakan model hubungan antara variabel

\footnotetext{
${ }^{18}$ V. Wiratna Sujarweni Dan Poli Endrayanto, “Statistika Untuk Penelitian”, (Yogyakarta: Ghara Ilmu,2012), Hlm. 177.

19 Ibid, hlm. 186.

${ }^{20}$ R. Guanawan Sudarmato," statistik terapan berbasis komputer; dengan program IMB SPSS statistcs", (Jakarta: mitra wacana media, 2013), hlm. 104-105

21 Ibid, hlm. 107.

${ }^{22}$ Ibid, hlm. 283.
} 
tidak bebas (y) dan variabel bebas (x). Analisis ini dimaksudkan untuk mengetahui besarnya pengaruh kualitas pelayanan multy payment online terhadap kepuasan nasabah pegadaian syariah cabang jokotole pamekasan dengan menggunakan rumus regresi linier sederhana. Bentuk umum persamaan regresi linier sederhana dapat ditulis sebagai berikut. ${ }^{23}$

$\mathrm{Y}=\mathrm{a}+\mathrm{bX}$

Diamana :

$\mathrm{Y}=$ variabel terikat yang diproyeksikan yaitu kepausan nasabah

$\mathrm{X}=$ variabel bebas mempunyai nilai tertentu untuk diprediksikan yaitu kualitas

pelayanan

$\mathrm{a}=$ nilai kostanta harga $\mathrm{Y}$ jika $\mathrm{X}=0$

$\mathrm{b}=$ nilai arah sebagai penentu ramalan yang menunjukkan nilai peningkatan atau nilai penurunan variabel Y

b. Uji t

Uji t dirumuskan:

$t^{0}=\frac{b-B_{0}}{S_{b}}$

Keterangan :

B0 : mewakili nilai B tertentu, sesuai hipotesisnya.

$\mathrm{Sb}$ : simpangan baku koefisien regersi $\mathrm{b}$

\section{c. Koefisien determinasi}

Koefisien korelasi yang dikuadratkan $\left(\mathrm{r}^{2}\right)$ dinamakan dengan koefisien determinasi atau koefisien penentu. Koefisien determinasi merupakan proporsi untuk menentukan terjadinya persentase variansi bersama antara variabel $\mathrm{X}$ dengan variabel Y jika dikalikan dengan 100\%. Oleh karena itu, besarnya koefisien determinasi adalah 0 $\leq \mathrm{r}^{2} \leq 1$ dan tidak ada koefisien determinasi yang bertanda negatif karena dikuadratkan. Untuk memberikan gambaran secara visualisasi misal variabel motivasi (X) merupakan prediktor untuk variabel prestasi (Y), maka koefisien dertminasi menunjukkan beberapa persen variabel prestasi (Y) dijelaskan oleh variabel motivasi (X). Hubungan antara motivasi dengan prestasi belajar diperoleh $r=0,70$ akan diperoleh koefisien determinasi sebesar $0,70^{2}=0,49 \times 100 \%=49 \%$. Dengan demikian dapat dikatakan $49 \%$ variasi prestasi dengan dijelaskan oleh motivasi belajar dean sebesar 51\% sisnya dijelaskan oleh variabel lainnya diluar motivasi belajar yang dinamakan koefisien aliansi. ${ }^{24}$

\section{HASIL DAN PEMBAHASAN}

Berdasarkan penelitian "Pengaruh Kualitas Pelayanan Multy Payment Online (Mpo) Terhadap Kepuasan Nasabah Pegadaian Syariah Cabang Jokotole Pamekasan” diperoleh informasi umum sebagai berikut:

\section{Tabel 1.1}

Hasil Uji Validitas Tiap Item Pernyataan Dari Variabel Kualitas Pelayanan (X) Dan Variabel Kepuasan (Y)

\begin{tabular}{|l|l|l|l|l|}
\hline No & Pernyataan & Kolerasi & Kritik (r) & Keterangan \\
\hline
\end{tabular}

\footnotetext{
${ }^{23}$ Andi Supangat, "statistika; dalam kajian deskriptif, inferensi, dan nonparametrik", (Jakarta: prenademia group,2007), hlm. 334.

${ }^{24}$ Budi Susetyo, "statistika untuk analisis data penelitian; dilengkapi cara perhitungan dengan SPSS dan ms office excel", (PT. Refika aditama,2010), hlm. 122.
} 


\begin{tabular}{|l|l|l|l|l|}
1 & X. 1 & 0,637 & 0,138 & Valid \\
\hline 2 & X. 2 & 0,594 & 0,138 & Valid \\
\hline 3 & X. 3 & 0,521 & 0,138 & Valid \\
\hline 4 & X. 4 & 0,707 & 0,138 & Valid \\
\hline 5 & X. 5 & 0,720 & 0,138 & Valid \\
\hline 6 & X. 6 & 0,668 & 0,138 & Valid \\
\hline 7 & X. 8 & 0,694 & 0,138 & Valid \\
\hline 8 & X. 9 & 0,677 & 0,138 & Valid \\
\hline 9 & X. 10 & 0,508 & 0,138 & Valid \\
\hline 10 & X. 11 & 0,647 & 0,138 & Valid \\
\hline 11 & Y. 1 & 0,798 & 0,138 & Valid \\
\hline 12 & Y. 2 & 0,885 & 0,138 & Valid \\
\hline 13 & Y. 3 & 0,784 & 0,138 & Valid \\
\hline
\end{tabular}

Sumber: data primer diolah dengan SPSS, 2019

Berdasarkan tabel 4.4 di atas dapat diketahui bahwa nilai $\mathrm{r}_{\text {hitung }}$ pada kolom korelasi

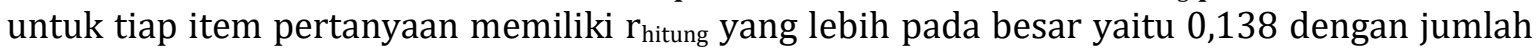
sampel adalah 240 responden $(n=240)$. Sehingga dapat disimpulkan dari variabel X Kualitas Pelayanan MPO dan variabel Y Kepuasan Nasabah adalah valid. Selanjutnya data tersebut dapat uji ketahap berikutnya.

Tabel 1.2

Hasil Uji Reliabilitas Instrumen

\begin{tabular}{|l|l|l|}
\hline Variabel & Cronbach Alpha & Keterangan \\
\hline $\begin{array}{l}\text { Kualitas Pelayanan } \\
\text { MPO }(\mathrm{X})\end{array}$ & 0,831 & Reliabel \\
\hline Kepuasan Nasabah & 0,819 & Reliabel \\
\hline
\end{tabular}

Sumber : Out SPSS, data primer diolah 2019

Dari tabel tersebut dapat diketahui bahwa variabel $\mathrm{X}$ memiliki cronbach alpha sebesar 0,831, sedangkan variabel Y memiliki cronbach alpha sebasar 0,819, artinya masingmasing variabel tersebut memiliki nilai cronbach alpha yang lebih tinggi dari ukuran tingkat reliabel yaitu sebesar 0,138. Sehingga dapat disimpulkan semua variabel X dan Y reliabel.

Tabel 1.3

t Tabel

Uji Autokorelasi

\begin{tabular}{ll|l|l|l|l}
\hline Model & $\mathrm{R}$ & R Square & $\begin{array}{l}\text { Adjusted } \\
\text { Square }\end{array}$ & $\begin{array}{l}\text { Rtd. Error of } \\
\text { the Estimate }\end{array}$ & $\begin{array}{l}\text { Durbin- } \\
\text { Watson }\end{array}$ \\
\hline 1 &, $154^{\mathrm{a}}$ &, 024 &, 020 & 1,59722 & 2,215 \\
\hline
\end{tabular}

a. Predictors: (Constant), kualitas pelayanan

b. Dependent Variable: kepuasan nasabah

Sumber : output SPSS, data primer 2019

Dari tabel tersebut diperoleh DW 2,215, maka untuk mengetahui ada tidaknya tabel autokorelasi, nilai DW tersebut akan dibandingkan dengan DW tabel sebagai berikut:

Tabel 1.4 
Hasil Pengujian Asumsi Klasik Autokolerasi

\begin{tabular}{|l|l|l|l|l|l|}
\hline dI & DU & $\mathbf{4}-\mathbf{d L}$ & $\mathbf{4}-\mathbf{d U}$ & $\mathbf{D W}$ & keputusan \\
\hline 1,758 & 1,778 & 2,2416 & 2,222 & 2,215 & $\begin{array}{l}\text { Tidak ada } \\
\text { autokolerasi }\end{array}$ \\
\hline
\end{tabular}

Sumber: output SPSS, data primer dioalah 2019

Nilai DW 2,215 dipeoleh dari tabel durbin-waston dengan ketentuan $=5 \%$, dimana $\mathrm{n}$ ( sampel) $=240$ serta $\mathrm{k}$ (jumlah variabel bebas) $=1$

Dari tabel di atas dapat dilihat bahwa nilai DW sebesar 2,215 berada diantara nila dU $=1,778$, dan nilai $4-\mathrm{dU}=2,222$ ( $\mathrm{dU}<\mathrm{DW}<(4-\mathrm{dU})$ ), sehingga dapat disimpulkan bahwa dalam model regresi tidak terjadi autokorelasi.

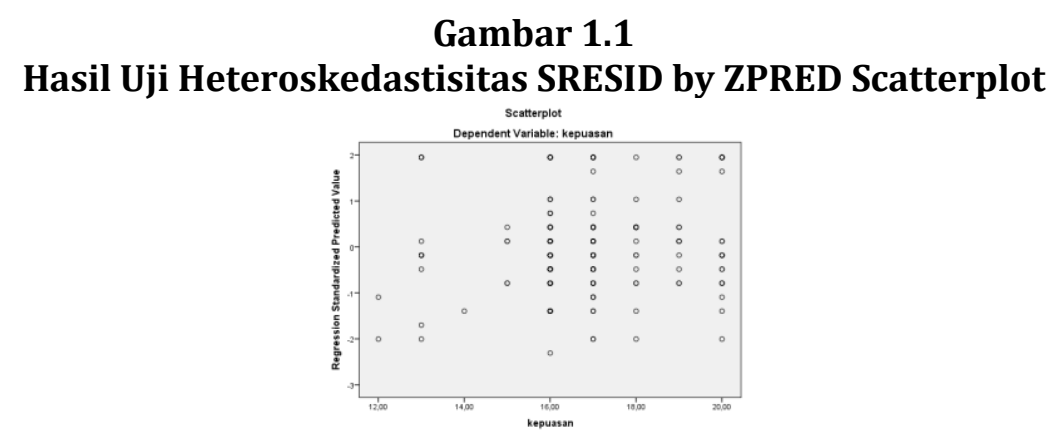

Sumber : output SPSS, data primer diolah 2019

Dari grafik scatterplot memperlihatkan bahwa titiktitik pada grafik tidak bisa membentuk pola tertentu yang jelas, diamna titik-titik pada grafik bisa dan dibawah angka 0 pada sumbu Y, sehingga grafik tersebut bisa dibaca dengan jelas. Hasil ini memperlihatkan bahwa tidak bisa dengan jelas. Hasil ini memperlihatkan bahwa tidak bisa terjadi heteroskedastisitas. Namun demikian, jika hanya melihat hasil output grafik scatterplot, dapat menimbulkan penilian yang subjektif dan kurang tepat. Oleh karena itu, untuk lebih memastikan bahwa tidak terjadi heteroskedastisitas pada model regresi, dalam penelitian ini juga dilakukan uji Glejser. Berikut hasil uji Glejser penelitian ini:

\section{Tabel 1.5}

\section{Hasil uji Glejser}

\begin{tabular}{ccccccc} 
& \multicolumn{5}{c}{ ANOVA $^{\mathbf{a}}$} \\
& Sodel & Sum of & & Mean & & \\
\hline 1 & Regressio & 61,564 & 1 & 61,564 & 5,809 &, $017^{\mathrm{b}}$ \\
$\mathrm{n}$ & & & & & \\
& Residual & 2522,419 & 238 & 10,598 & & \\
& Total & 2583,983 & 239 & & & \\
\hline
\end{tabular}

a. Dependent Variable: kualitas pelayanan

b. Predictors: (Constant), kepuasan nasabah

Sumber : output SPSS, data primer diolah 2019 
Dari tabel 4.8 di atas dapat diketahui bahwa nilai signifikansi variabel independen (Kualitas Pelayanan MPO) 0,292 adalah lebih besar dari taraf sig. 0,05. Oleh karena itu, dapat disimpulkan bahwa model regresi tidak terjadi heteroskedastisitas.

\section{Gambar 1.2}

\section{Hasil Uji Normalitas}

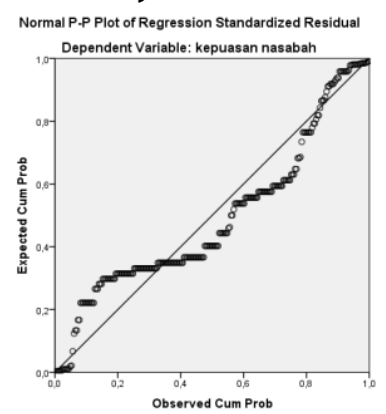

Sumber : output SPSS, data primer diolah 2019

Dari hasil output SPSS diatas, pada grafik normal non probability plot menunjukkan bahwa data (titik-titik) menyebar di sekitar garis diagonal dan mengikuti arah garis diagonal, maka dapat disimpulkan model regresi memenuhi asumsi normalitas.

Namun demikian, seperti halnya pada uji hetetos kedastisitas yang menggunakan gfafik normal probability plot, ada kemungkinan subjektivitas dalam menginterpretasikan hasil grafik tersebut. Oleh karena itu, untuk lebih memastikan bahwa model regresi memenuhi asumsi normalitas, maka dalam penelitian ini juga melakukan One-Sample Kolmogorov-Smirnov. Berikut hasil uji One-Sample Kolmogorov-Smirnov penelitian ini:

Tabel 1.6

Hasil Uji Kolmogorov Smirnov One-Sample Kolmogorov-Smirnov Test

Unstandardiz ed Residual

\begin{tabular}{|c|c|c|}
\hline $\mathrm{N}$ & & 240 \\
\hline \multirow[t]{2}{*}{ Normal Parametersa,b } & Mean & ,0000000 \\
\hline & Std. Deviation & 1,59387474 \\
\hline \multirow{3}{*}{$\begin{array}{l}\text { Most } \\
\text { Differences }\end{array}$} & Absolute & ,147 \\
\hline & Positive & ,138 \\
\hline & Negative &,- 147 \\
\hline \multicolumn{2}{|l|}{ Test Statistic } & , 147 \\
\hline \multicolumn{2}{|l|}{ Asymp. Sig. (2-tailed) } &, $000^{c}$ \\
\hline
\end{tabular}

a. Test distribution is Normal.

b. Calculated from data.

c. Lilliefors Significance Correction.

Sumber : output SPSS, data primer diolah 2019 
Berdasarkan hasil uji normalitas, diperoleh nilai kolmogorov-smirnov Z sebesar 0,147 lebih besar dari 0,05, ini berarti bahwa data berdistribusi normal.

Tabel 1.7

Hasil Analisis Regresi Linier Sederhana

\section{Coefficients $^{\mathrm{a}}$}

\begin{tabular}{|c|c|c|c|c|c|c|}
\hline \multirow{2}{*}{\multicolumn{2}{|c|}{ Model }} & \multicolumn{2}{|c|}{$\begin{array}{l}\text { Unstandardized } \\
\text { Coefficients }\end{array}$} & \multirow{2}{*}{$\begin{array}{l}\text { Standardiz } \\
\text { ed } \\
\text { Coefficients } \\
\text { Beta } \\
\end{array}$} & \multirow[b]{2}{*}{$\mathrm{T}$} & \multirow[b]{2}{*}{ Sig. } \\
\hline & & $\mathrm{B}$ & Std. Error & & & \\
\hline 1 & (Constant) & 13,062 & 1,530 & & 8,536 &, 000 \\
\hline & $\begin{array}{l}\text { kualitas } \\
\text { pelayanan }\end{array}$ & ,076 & ,031 & ,154 & 2,410 & 017 \\
\hline
\end{tabular}

a. Dependent Variable: kepuasan nasabah

Sumber : output SPSS, data primer diolah 2019

Berdasarkan hasil analisis regresi linier sederhana pada tabel tersebut diperoleh koefisien independet Kualitas Pelayanan $(X)=0,076$ serta konstanta sebesar $=13,062$, sehingga model persamaan regresi yang diperoleh dalam penelitian adalah sebagai berikut: $\mathrm{Y}=13,062+0,076 \mathrm{X}$

Dari model persamaan tersebut dapat diinterpretasikan sebagai berikut:

1) Konstanta sebesar 13,062 menyatakan bahwa jika variabel independen tetap, maka variabel dependennya sebesar 13,062.

2) Hasil regresi menunukkan variabel Kualitas Pelayanan sebesar 0,076 peningkatkan $1 \%$ maka variabel dependen (kepuasan nasabah) akan mengalami peningkatan sebesar 7,6 $\%$. Pada persamaan tersebut nilai koefisien untuk variabel Kualitas Pelayanan adalah positif. Hal ini berarti pengaruh variabel independent terhadap variabel dependent adalah positif. Hal ini berarti pengaruh variabel independent adalah positif. Sifat pengaruh yang positif menunjukkan bahwa apabila terjadi peningkatan terhadap variabel independent maka kepuaan anggota dalam menggunkan kualitas pelayanan MPO juga akan meningkat.

Tabel 1.8

Hasil Uji-t

\section{Coefficients ${ }^{a}$}

\begin{tabular}{lll|l|l|l|l}
\hline & \multicolumn{3}{l}{\begin{tabular}{l}
\multicolumn{2}{l}{ Unstandardized } \\
Coefficients
\end{tabular}} & $\begin{array}{l}\text { Standardize } \\
\text { d }\end{array}$ & & \\
Model & Coefficients & & \\
\hline 1 & B & Std. Error & Beta & T & Sig. \\
\hline & $\begin{array}{l}\text { (Constant) } \\
\text { kualitas } \\
\text { pelayanan }\end{array}$ & 13,062 & 1,530 & & 8,536 &, 000 \\
\hline
\end{tabular}

a. Dependent Variable: kepuasan nasabah

Sumber : output SPSS, data primer diolah 2019

Dari tabel analisis uji-t tersebut, hasil $t$ hitung untuk Kualitas Pelayanan MPO (X) diperoleh sebesar 2,410 lebih besar 1,972 lebih besar dari $t$ tabel 1,972 dengan taraf signifikan 0,17 lebih kecil dari signifikan 0,05, hal ini menunjukkan bahwa $t_{\text {hitung }}>\mathrm{t}_{\text {tabel }}$ dan taraf 
signifikan sebasar 0,017 $<0,05$ maka Ha diterima, artinya kualitas pelayanan MPO mempunyai pengaruh kepuasan nasabah.

\section{Tabel 1.9 \\ Hasil Uji Koefisien Determinasi}

Model Summaryb
\begin{tabular}{ll|l|l|l|l} 
Model & $\mathrm{R}$ & R Square & $\begin{array}{l}\text { Adjusted } \\
\text { Square }\end{array}$ & $\begin{array}{l}\text { R } \\
\begin{array}{l}\text { Std. Error of } \\
\text { the Estimate }\end{array}\end{array}$ & $\begin{array}{l}\text { Durbin- } \\
\text { Watson }\end{array}$ \\
\hline 1 &, $154^{\mathrm{a}}$ &, 024 &, 020 & 1,59722 & 2,215 \\
\hline
\end{tabular}

a. Predictors: (Constant), kualitas pelayanan

b. Dependent Variable: kepuasan nasabah

Hasil analisis data pada tabel 4.13 di atas dapat diketahui bahwa besarnya $\mathrm{R}$ Square adalah 0,024 atau 2,4\% yang berarti bahwa variabel independen (kualiats pelayanan MPO) mampu menjelaskan variabel dependen (kepuasan nasabah) sebesar 2,4\%. Sedangkan sisanya $(100 \%-2,4 \%=97,4 \%)$ dipengaruhi oleh variabel-variabel lainnya yang tidak diperhitungkan dalam analisis penelitian ini.

Dari hasil koefisien regresi linear variabel independen (Kualitas pelayanan MPO) yang bernilai positif yaitu sebesar 0,076. Hal ini berarti bahwa kualitas pelayanan MPO mempunyai hubungan yang positif terhadap kepuasan nasabah sehingga setiap terjadi peningkatan sebesar $1 \%$ pada kualitas pelayanan MPO maka minat nasabah akan meningkatkan sebesar 7,6\%. Pada persamaan tersebut nilai koefiseien regresi untuk variabel kualitas pelayanan MPO adalah positif. Hal ini berarti pengaruh variabel independent terhadap variabel dependent adalah positif menunjukkan bahwa apabila terjadi peningkatan terhadap variabel independent maka kepuasan anggota dalam menggunakan kualitas pelayanan MPO juga meningkat. Oleh karena itu Pegadaian Syariah Cabang Jokotole Pamekasan harus memelihara, menjaga dan meningkatkan Kualitas pelayanan Multy Payment Online (MPO) sehingga mampu membuat anggota tertarik dan dapat meningkatkan jumlah anggotanya.

Hasil hipotesis setelah di uji menggunakan uji $t$ adanya pengaruh anatra Kualitas pelayanan MPO terhadap kepausan nasabah. Hal ini dapat dibuktikan dari nilai koefisien korelasi variabel independen (Kualitas Pelayanan MPO) menunjukkan $\mathrm{t}$ hitung $(2,410)>\mathrm{t}$ tabel $(1,972)$ dengan taraf signifikan sebesar 0,017 yang lebih kecil dari 0,05 , hal ini menunjukkan bahwa $t_{\text {hitung }}>\mathrm{t}$ tabel dan taraf signifikan sebesar 0,017 < 0,05 maka Ha diterima, artinya kualitas pelayanan MPO mempunyai pengaruh terhadap kepuasan anggota.

Untuk menarik minta anggota tidak hanya mengutamakan Kualitas Pelayanan yang bagus, akan tetapi juga dibutuhkan pengetahuan dan keterampilan khusus dalam menggunkan Kualitas pelayanan MPO.

Dari hasil nilai koefiseien deretminasi $\left(\mathrm{R}^{2}\right)$, dimana dalam tabel penelitian ini dilihat pada bagian $\mathrm{R}$ Square yaitu 0,024 atau 2,4\%. Hal ini berati bahwa kontribusi variabel independent (Kualitas Pleayanan MPO) terhadap variabel dependen (Kepuasan Nasabah) pada Pegadaian syariah cabang jokotole pamekasan berpengaruh, sedangkan sisanya 97,4\% kemungkinan dipengaruhi oleh variabel=variabel lain yang tidak diperhitungkan dalam analisis penelitian ini.

Kualitas pelayanan MPO hanya sebagian kecil dari variabel yang dipengaruhi, masih banyak variabel yang mempengaruhi kepuasan diantaranya yaitu: a. Fitur produk dan jasa; kepuasan pelanggan terhadap produk jasa secara signifikan dipengaruhi oleh evaluasi pelanggan terhadap fitur dan jasa secara signifikan dipengaruhi oleh evaluasi pelanggan 
terhadap fitur atau jasa. b. Emosi pelanggan: emosi juga dapat mempengaruhi persepsi pelanggan terhadap produk atau jasa. c. Atribut untuk keberhasilan atau kegagalan jasa: atribut penyebab yang dirasakan dari suatu peristiwa mempengaruhi persepsi dari kepuasan. d. Persepsi terhadap kewajaran dan keadilan (equity and fairness): kepuasan pelanggan juga dipengaruhi oleh persepsi pelanggan terhadap kewajaran dan keadilan. e. Pelanggan lain, keluarga, dan rekan kerja: kepuasan pelanggan juga dipengaruhi oleh orang lain. Seseorang yang memang sudah menggunakan suatu jasa apabila orang itu puasa maka ia akan mempromosikannya kepada orang lain, ia akan menyarankan orang lain untuk menggunakan jasa yang sama dengan yang ia gunakan saat ini. Dalam atribusi untuk keberhasilan atau kegagalan jasa seperti halnya Multy Payment Online yang dimiliki oleh Pegadaian Syariah Cabang Jokotole Pamekasan yang merupakan atribut jasa dalam Pegadaian tersebut. Kaerna selain kegunaannya didalam memberikan kemudahan kepada nasabah dalam melakukan transaksi pembayaran secara online yang ada dipegadaian syariah yang bisa dilakukan diberbagai outlet pegadaian diseluruh Indonesia, yang nantinya akan menimbulkan rasa puas atau tidak puas bagi nasabahnya.

Dan dalam penelitian ini, banyak responden yang merasa puas dengan Kualitas pelayanan MPO. Banyak dari mereka yang melakukan pembayaran tagihan dengan MPO ketika akan bertanskasi dipegadaian syariah cabang jokotole pamekasan. Kepuasan nasabah dipengaruhi oleh pelayanan yang ramah dari para karyawan yang ada dilapangan.

Jadi variabel kepuasan dalam penelitian ini selain faktor eksternal juga dipengaruhi oleh faktor internal yaitu dari dalam diri nasabah itu sendiri sehingga kesimpulannya ada pengaruh yang signifikan pada Kualitas Pelayanan MPO cabang Jokotole terhadap kepausan nasabah pegadaian syariah cabang pamekasan.

\section{PENUTUP}

Hasil hipotesis setelah di uji menggunakan uji t adanya pengaruh anatra Kualitas pelayanan MPO terhadap kepausan nasabah. Hal ini dapat dibuktikan dari nilai koefisien korelasi variabel independen (Kualitas Pelayanan MPO) menunjukkan t hitung $(2,410)>t$ tabel $(1,972)$ dengan taraf signifikan sebesar 0,044 yang lebih kecil dari 0,05 , hal ini menunjukkan bahwa $\mathrm{t}$ hitung $>\mathrm{t}$ tabel dan taraf signifikan sebesar 0,017 $<0,05$ maka Ha diterima, artinya kualitas pelayanan MPO mempunyai pengaruh terhadap kepuasan anggota. Dari hasil nilai koefiseien deretminasi (R2), dimana dalam tabel penelitian ini dilihat pada bagian R Square yaitu 0,024 atau 2,4\%. Hal ini berati bahwa kontribusi variabel independent (Kualitas Pleayanan MPO) terhadap variabel dependen (Kepuasan Nasabah) pada Pegadaian syariah cabang jokotole pamekasan berpengaruh, sedangkan sisanya 97,9\% kemungkinan dipengaruhi oleh variabel=variabel lain yang tidak diperhitungkan dalam analisis penelitian ini.

\section{DAFTAR PUSTAKA}

Al Arif, M. Nurdianto, Dasar-Dasar Pemasaran, Bandung: Alfa Beta, 2010.

Andri, Wawancara Salah Satu Karyawan Pegadaian Syariah Cabang Jokotole Pamekasan.

Departemen Pendidikan Nasional, Kamus Besar Bahasa Indonesia, Jakarta: PT. Gramedia Pusat Bahasa,2008

Fandiy Tjiptono Dan Gregorius Candra, "Service Quality \& Satisfaction” Yogyakarta: CV. Andi Offset, 2005. 
Anna Fijriatul Latifah, Mohammad Bashri Asy'ari

Hasan Ali, "Marketing Bank Syariah: Cara Jitu Meningkatkan Pertumbuhan Pasar Bank Syariah", Bogor: Ghalia Indonesia,2010.

Husein, Umar, "Metode Penelitian Untuk Skripsi Dan Tesis Bisnis Edisi Kedua", Jakarta: Rajawali Pres, 2013.

Misbahun Dan Iqbal Hasan, "Analisis Data Penelitian Dengan Statistik", Jakarta: PT Bumi Aksara,2013.

Nining Catur Pawestriningtyas Dkk, "Pengaruh Kualitas Layanan Jasa Terhadap Nasabah (Survei Pada Nasabah Pegadaian Kantor Cabang Syariah Tlobo Mas Malang)”, Vol. 32 No. 2 Maret 2016, Jurnal Administrasi Bisnis, Diakses Tanggal 29 April 2018 Pukul 05.25 WIB.

Nurastuti Wiji, Teknologi Perbankan, Yogyakarta: Graha Ilmu, 2011

Rodoni, Ahmad, “Asuransi Dan Pegadaian Yariah", Jakarta: Mitra Wacana Media, 2015.

Soemitra, Andri, Bank Dan Lembaga Keuangan Syariah, Jakarta: Kencana Perdana Media,2009.

Sudarmato, R. Guanawan, Statistik Terapan Berbasis Komputer; Dengan Program IMB SPSS Statistcs, Jakarta: Mitra Wacana Media, 2013.

Suharmisi Arikunto, “Manajemen Penelitian”, Jakarta: Rineka Cipta,2013.

Sujarweni ,V. Wiratna Dan Poli Endrayanto, Statistika Untuk Penelitian, Yogyakarta: Ghara Ilmu,2012.

Supangat, Andi, Statistika; Dalam Kajian Deskriptif, Inferensi, Dan Nonparametrik, Jakarta: Prenademia Group,2007.

Supriono Maryanto, Buku Pintar Perbankan, Yogyakarta: CV Andi Offset, 2011.

Susetyo, Budi, Statistika Untuk Analisis Data Penelitian; Dilengkapi Cara Perhitungan Dengan SPSS Dan Ms Office Excel, PT. Refika Aditama,2010.

Syofiyan Siregar," Metode Penelitian Kuantitatif; Dilengkapi Dengan Perbandingan Perhitingan Manual \& SPSS", Jakarta: Kencana,2013.

Tim Penyusun Pedoman Penulisan Karya Ilmiah, Pedoman Penulisan Krya Ilmiyah ,Pamekasan: STAIN Press,2015.

Valerie A ,Zeithaml Dan Mary Jo Bitner, Service Marketing: Interating Costumer Focus Across The Firm Dalam Sentot Imam Wahjono, " Manajemen Pemasan Bank", Yogyakarta: Graha Ilmu,2010.

Wijaya Tony, Manajemen Kualitas Jasa, Jakarta: PT. Indek 2011.

Adityo Laksono, "Pengertian Kepuasan Pelanggan Dan Faktor-Faktor Yang Mempengaruhinya Menurut Para Ahli", Gudang Ilmu, Diakses Dari:

(Http://Adityolaksonono.26.Blogsopt.Co.Id/2015/03/Pengertian-Kepuasan-PelannganDan.Html?=1) Diaksestanggal 28 Januari 2019. 
Erikson Damanik,"Perancangan Sistem Informasi Pembayaran Online Menggunakan Paymen Gateway", Vol 13 No 1 April 2012 Jurnal JSM STIMK Mikro Skill Di Akses Tanggal 7 Mei 2018 Pukul 14.10 WIB.

Hestin Mulyasari Dkk, "Analisis Jenis Pembayaran Elektronik Dalam Transaksi E-Commerce Di Indonesia", ISSN : 2089-9813 Yogyakarta15 Maret 2014, Jurnal : Seminar Nasional Teknologi Informasi Dan Komunikasi 2014 (SENTIKA) Diakses Tanggal 4 April 2018 Pukul 12.43 WIB.

Maulana Yusuf Dan Medina Kurniawan, “ Pengaruh Sistem Pembayaran Listrik Online Payment Point Online Bank Terhdap Pengendalian Internal Kas Pada PT PLN (Persero) DJBB", Vol 6 No 1 April 2012 Jurnal Ekonomi, Bisnis Dan Enterpreneurship Diakses Tanggal 7 Mei 2018 Pukul 14.10 WIB.

Sonya Maharani “ Analisis Pengaruh Kualitas Pelayanan Terhadap Pelanggan Dalam Pembayaran Rekening Listrik (Studi Pada Unit Pelayanan Pelanggan Semarang Barat)", Universitas Diponegore Semarang, 2010.

Willy Tri Hardiyanto Analisis Pengaruh Kualitas Pelayanan Terhadap Kepuasan Pelanggan Dalam Pembayaran Rekening Listrik (Studi Pada Unit Pelayanan Pelanggan Di Probolinggo, Vol,2 No,2 Juli-Desember 2012, Diakses Tanggal 29 September 2018 Pukul 08.00 WIB. 